\title{
Influence of European Red Mite on Leaf and Whole-canopy Carbon Dioxide Exchange, Yield, Fruit Size, Quality, and Return Cropping in 'Starkrimson Delicious'Apple Trees
}

\author{
A.N. Lakso' ${ }^{1}$ G.B. Mattii ${ }^{2}$, J.P. Nyrop ${ }^{3}$, and S.S. Denning \\ Department of Horticultural Sciences, New York State Agricultural Experiment Station, \\ Geneva, NY 14456
}

Additional index words. Malus domestica, Panonychus ulmi, leaf area, leaf/fruit ratio, source, sink, carbon balance, integrated pest management, photosynthesis

\begin{abstract}
The hypothesis was tested that effects of late-season European Red Mite (ERM) [Panonychus ulmi (Koch)] injury on apple (Malus domestica Borkh.) fruit development are better explained by carbon physiology than by pest densities. Midseason ERM populations were allowed to develop in mature semi-dwarf 'Starkrimson Delicious'/M26 trees with moderately heavy crops, then were controlled with miticides at different mite-day (activity of one mite per leaf for 1 day) levels as estimated by weekly leaf sampling. The range of final mite-days was from 250 to 2100 on individual trees. Seasonal fruit growth patterns were monitored. Diurnal whole-canopy net $\mathrm{CO}_{2}$ exchange rate (NCER) was measured in eight clear flexible balloon whole-canopy chambers on several dates before and after mite infestations. Mite injury reduced fruit growth rates. Leaf and whole-canopy NCER were reduced similarly. Late season fruit growth and final fruit size were correlated with accumulated mite-days, but were better correlated to whole-canopy NCER per fruit. Fruit firmness, color, soluble solids and starch ratings showed no correlation to mite-days. Number of flower clusters per tree and final fruit per tree the following year were not related to accumulated mite-days, but final fruit per tree the following year were better correlated to whole-canopy NCER per fruit. These results generally supported the hypothesis.
\end{abstract}

A fundamental concept of integrated pest management (IPM) is that crop plants can tolerate some level of foliar pest injury before the crop is economically affected, leading to the concept of action or economic thresholds (Pedigo et al., 1986; Stern et al., 1959). Although early development of IPM emphasized pest dynamics and ecology, there has been increasing recognition of the importance of variations in the host plant physiology (Funderburk, 1993; Higley et al., 1993; Welter, 1993).

Pest management action thresholds for foliar pests of apple, such as European red mite (ERM), (Panonychus ulmi), spotted tentiform leafminer (Phyllonorycter blancardella Fabr. and crataegella Clemens), and white apple leafhopper (Typhlocyba pomaria McAtree) have been estimated with field trials examining effects of pest densities on yield, fruit quality or return bloom (Beers et al., 1988; Hull and Beers, 1990; Reissig et al., 1982). However, there have been relatively few studies of leafminers and leafhoppers, and the results have been variable in the case of the ERM.

Most research on the thresholds for foliar pests on apple trees has been with mites, especially ERM. This is due to the combination of ubiquity, importance and manageability of ERM compared with the other foliar pests. Some of the reported effects of mites and other foliar feeders on apples are reductions in 1) leaf net $\mathrm{CO}_{2}$ exchange rates (NCER) (Avery, 1963; Ferree and Hall, 1980; Mobley and Marini, 1990; Welter, 1989); 2) yield due to reduc-

Received for publication 18 Oct. 1995. Accepted for publication 11 Apr. 1996. This research was funded in part by the Consiglio Nazionale delle Ricerche, Italy (fellowship to G.B. Mattii). The advice on whole tree chamber design by Luca Corelli Grappadelli, and the editorial help of A.H.D. Francesconi and P.C. Andersen are gratefully acknowledged. Use of trade names does not imply endorsement of the products named nor criticism of similar ones not named. The cost of publishing this paper was defrayed in part by the payment of page charges. Under postal regulations, this paper therefore must be hereby marked advertisement solely to indicate this fact.

${ }^{1}$ To whom reprint requests should be addressed.

${ }^{2}$ Dipartimento di Ortoflorofrutticoltura, Universitá di Firenze, 50144 Firenze, Italy.

${ }^{3}$ Dept. of Entomology. tions in fruit size and/or fruit numbers; 3) fruit quality via poor color; reduced sugar concentrations or delayed maturity or earlier fruit abscission; and 4) subsequent year crops due to poor return bloom (Ames et al., 1984; Beers et al., 1987, 1990; Chapman et al., 1952; Lienk et al., 1956; Lienk and Minns, 1980; Zwick et al., 1976) . The results, however, have been extremely variable. This variation is likely due to differences in the environment, the timing and severity of pest stress, or the physiological status of the tree, especially crop load.

In a few cases nonpest factors have been examined for their interactions with mite injury. Severity of response to ERM has been found to be greater with higher crop loads with relatively few effects in nonstressed lighter-cropped trees (Ames et al., 1984; Marini et al., 1994; Zwick et al., 1976). Beers et al. (1987) proposed that carbon balance was involved but concluded that crop load did not interact with mite stress. Their use of individual branch treatments were likely confounded since it has been shown that branches are not independent for carbohydrate transport (Haller and Magness, 1933; Hansen and Christensen, 1974; Palmer et al., 1991). Unfortunately, few pest effect studies have provided data on tree crop load.

Since mites and other foliar pests reduce leaf NCER, carbohydrate physiology may be an integrating mechanism of foliar injury as discussed by Beers et al. (1987). Considerable experimental and modeling research has been done on the carbohydrate production and distribution in the apple tree (reviewed by Hansen, 1977; Flore and Lakso, 1989; Jackson, 1980; Lakso, 1994; Lakso et al., 1989; Oliveira and Priestley, 1988). The development of moderate to heavy apple crops may be limited by carbohydrate supply at critical periods around fruit set and late in the season before harvest when radiation and temperatures may be less than optimum for whole-tree NCER (Lakso, 1992, 1994; Lakso and Corelli Grappadelli, 1992; Lakso and Johnson, 1990). The late season is the period when ERM populations increase in the New York climate.

Based on the above discussion, the following hypothesis is proposed. 
Effects of middle- to late-season ERM stress on apple trees are mediated by a reduction of carbohydrate production in relation to the demands of the crop. Therefore, an expression of the carbohydrate supply/demand balance of the apple tree, whole-canopy NCER per fruit, will better explain variations in ERM effects on fruit development and tree productivity than measuring pest densities alone.

The specific objectives of the research were to determine 1) the effects of varying levels of ERM injury on leaf and whole-canopy NCER, yield, fruit development and final quality and 2) if wholecanopy NCER per fruit was correlated to variations in ERM effects on fruit development and productivity better than pest densities alone.

\section{Materials and Methods}

Sixteen apple trees of 10-year-old 'Starkrimson Delicious'/ M26 in a hedgerow planting at the New York State Agricultural Experiment Station, Geneva, N.Y., in two rows were selected for uniformity of trunk cross-sectional area (TCSA), height, width, and vigor, canopy density, bloom density and previous year's yields. The trees were planted at $3 \times 4.6 \mathrm{~m}$. Fertilization, weed and disease control practices followed Cornell Univ. standard recommendations except for special practices related to mite management explained below.

At bloom, fruiting and nonfruiting spurs on every selected tree were counted. To establish uniform commercial crops, the trees were hand thinned about 2 weeks after bloom to fruit numbers calculated to give commercial crop loads averaging $5 \mathrm{fruit} / \mathrm{cm}^{2}$ TCSA. Four ERM target threshold treatments $(0,500,1000$, and 2000 mite-days) were established on four trees/treatment to provide a range of mite injury levels from below to well above the suggested thresholds of 500 to 700 mite-days for New York. Due to differences in the exposure of the two rows caused by different guarding of the rows, each row was treated as a block. Within each block, two trees were randomly assigned to each treatment. Each treatment tree was buffered within the row by at least one buffer tree to minimize spray drift or mite dispersal.

Mite management and sampling. Insecticides were used as needed to control other arthropod pests, and were chosen to have minimal effect on mites. The presence of adequate numbers of ERM eggs on the test trees and an appropriate pesticide program allowed natural infestations to develop. Mite-day accumulations were determined by sampling 20 spur and shoot leaves per tree from around the canopy at a range of heights at 7- to 15-day intervals during the early season, and at 7-day intervals during the ERM buildup in July and August. Effort were made to make the sample representative of the exposed canopy. The leaves were brought back to the laboratory, brushed with a mite brushing machine (Leedom Engineering, Santa Clara, Calif.) onto glass plates coated with an adhesive mixture of polyoxyethylene (Tween 80 ) and $95 \%$ ethanol (1:2 parts respectively). The number of motile mites per plate were counted under a dissecting microscope. Population densities were expressed as cumulative mite-days (CMD) per leaf by accumulating mite-days at each sampling date as: mite-days $=\left[0.5\left(m p l_{p}+m p l_{c}\right)\right] \times \mathrm{d}_{c-p}$ where $m p l_{p}$ is the number of mites per leaf at the prior sampling date, $m p l_{c}^{p}$ is the current number of mites per leaf and $\mathrm{d}_{c-p}$ is the interval of days between the samples (Beers et al., 1990).

When average target mite-day levels were reached, each set of treatment trees was sprayed with a commercial rate of Omite (propargite). Trees that were not treated were protected by plastic shielding to avoid drift. Since the first spray did not completely eradicate the ERM populations, a spray of Carzol (formetenate hydrochloride) was applied 1 week later using a hand sprayer to all trees. Although the timing varied by a few days, all trees received two miticide treatments. Unfortunately, since the first miticide did not provide complete control of ERM for the zero mite-day treatment, extremely low mite-day accumulations were not achieved.

Tree measurements. Sixteen representative fruit per tree in different parts of the canopy were tagged early in the season to monitor fruit growth with electronic calipers at about 10-day intervals before and after mite infestations to examine effects on fruit growth rates during the season. At harvest, yields and fruit numbers were measured for each tree. Fruit fresh weight, firmness, visual color, starch rating, soluble solids by refractometer, and dry weight were determined on representative 25-fruit fruit samples per tree. To examine return bloom and cropping effects, the number of flower clusters and the final numbers of fruit on each tree were counted the following season. All trees received normal cultural and pest management practices. A commercial chemical thinning treatment of $10 \mathrm{ppm}$ naphthalene acetic acid at the $10-\mathrm{mm}$ fruit size stage was applied since response to chemical thinning may be influenced by previous years' cropping and physiological status (Williams, 1979).

Physiological measurements. Net $\mathrm{CO}_{2}$ exchange rate (NCER) of whole apple tree canopies was determined by enclosing the canopies of all trees in one block in eight clear whole tree chambers similar to those described by Corelli Grappadelli and Magnanini (1993), but with a few modifications. The chambers were made of
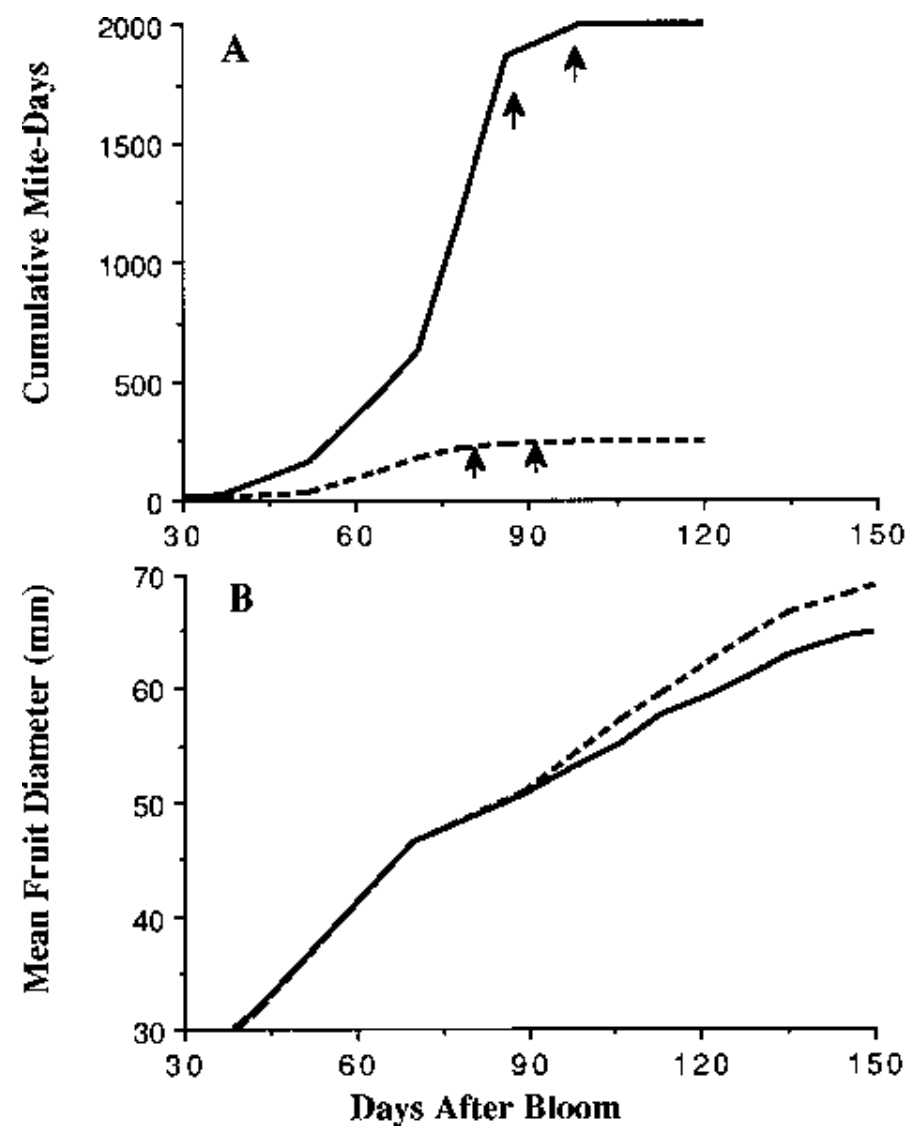

Fig. 1. Ranges of seasonal accumulations of European red mite-days (A) and fruit diameter growth curves (B) of fruit on trees of 'Starkrimson Delicious' apple that had the lowest and highest cumulative mite-days (CMD). Each fruit growth curve is the mean of 16 fruit. 
clear 0.025-mm Mylar film (Du Pont, Wilmington, Del.) and were shaped to fit closely over the tree canopies, enclosing about 5500 L in volume. The turnover rate of about 1.2 to 1.3 volumes/min and the large leaf area per volume provided acceptably small temperature increases of typically 2 to $3{ }^{\circ} \mathrm{C}$ under sunny conditions. Flow rates were estimated by measuring air flow velocity in the center of the pipe in a 2-m straight section before entering the chamber with a microanemometer (Solomat Neotronics Co., Norwalk, Conn.). The velocities were multiplied by a velocity-to-flow calibration factor determined by the dilution of known flow rates of pure $\mathrm{CO}_{2}$ injected into the pipe system. The $\mathrm{CO}_{2}$ and humidity differentials across the inlets and outlets of the chambers were measured with an infrared gas analyzer (LCA2; ADC Inc., Hoddesdon, Herts., U.K.). Air temperatures at the inlet and outlet and at varying locations were taken with the temperature sensor of the Solomat instrument.

Whole-canopy NCER readings were taken 8 times during the growing season with eight chambers installed on eight trees in one row in the morning at about 4 to $5 \mathrm{~h}$ before solar noon on clear days. Gas exchange measurements were made at about 45- to 90-min intervals through the day for 7 to $8 \mathrm{~h}$. The chambers were then removed and installed on the trees in the other block the next day. Generally both sets of trees could be measured under clear conditions; but at times, the weather did not allow both blocks to be measured under clear conditions for the entire day at every time period.

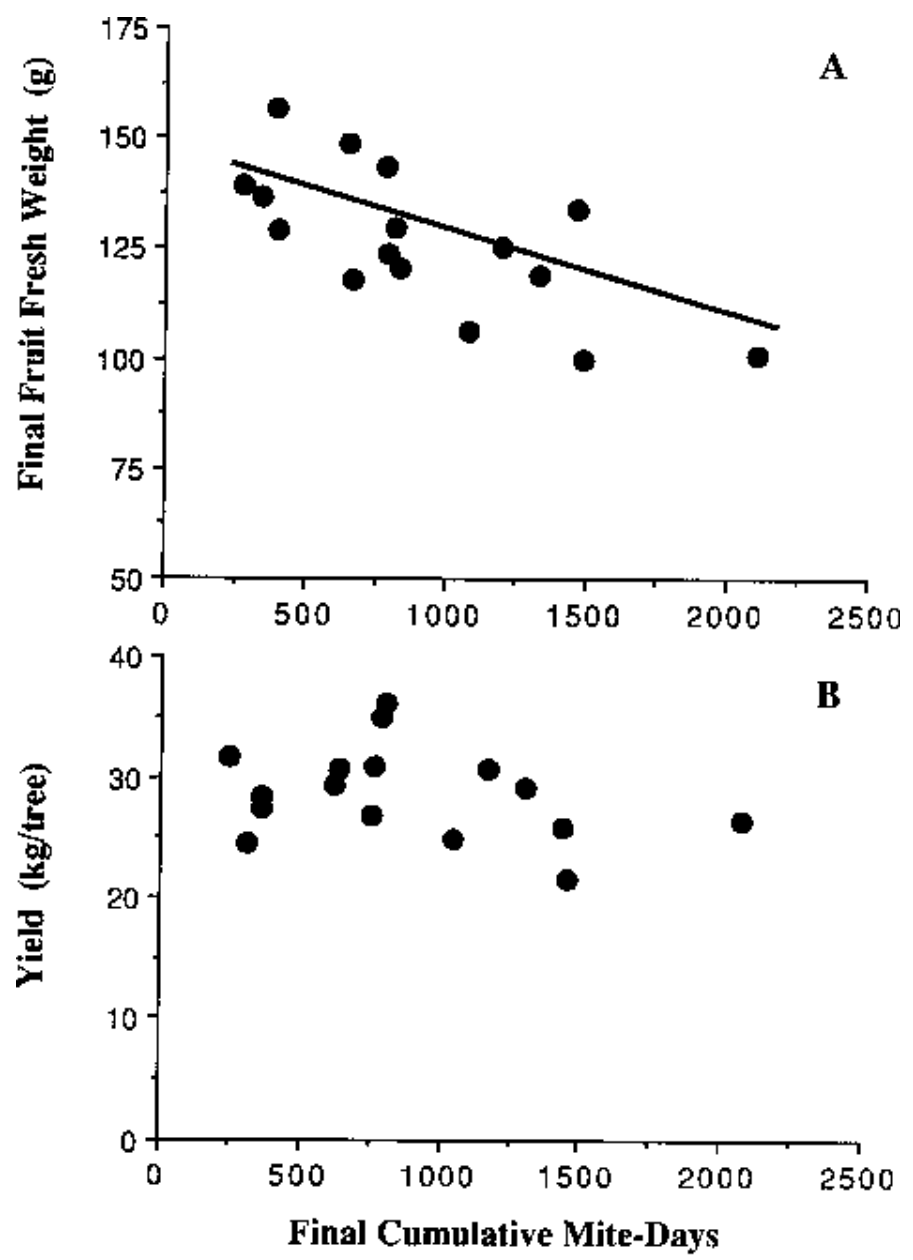

Fig. 2. Final tree means for fruit fresh weights (A) and yields per tree (B) of 'Starkrimson Delicious' apple trees related to seasonal accumulations of European red mite-days. Linear regression for fruit weight is $\mathrm{y}=144.2$ 0.0222 CMD $r^{2}=0.47, P<0.003$.
On 9 and 25 Sept. (115 and 129 d after full bloom and after mite injury occurred), single-leaf NCER (net photosynthesis) was measured from four representative well-exposed leaves per tree under clear, sunny conditions with the ADC portable photosynthesis system with the broad leaf chamber.

Statistical analyses. Although ERM target levels were used, a range of ERM cumulative injury was expected and found. With the range of the mite-day accumulations and some natural variation in the final crop level on each tree, a good range in cumulative mitedays and canopy NCER per fruit was obtained. Regression analysis was used to evaluate the relationships of tree performance to mite-days or canopy NCER per fruit.

\section{Results and Discussion}

Mite development. The seasonal development of mite injury showed a rapid increase in CMD in late July and early August, about 70 to $80 \mathrm{~d}$ after bloom when the fruit were 40 to $50 \mathrm{~mm}$ in diameter (Fig. 1A). Although the CMD values did not reach all targeted levels, the range of CMD was from 250 to 2100 , above and below the 500 CMD action threshold used to begin control measures in New York. This provided a good range of mite injury for the regression analyses of mite effects.

Fruit growth and yields. The greatest effects of ERM were to reduce post-infestation fruit growth and final fruit weights. When the CMD increased rapidly at 75 to $90 \mathrm{~d}$ after bloom (the extreme trees showing range given in Fig. 1A), fruit growth rates declined thereafter in the trees with the high CMD (the extreme trees showing range given in Fig. 1B). Since fruit diameters were similar in all trees up to $60 \mathrm{~d}$ after bloom, most variation in final fruit size was due to differences in the post-injury period of fruit growth. Final fruit size was negatively related to CMD (Fig. 2A). Although the relationship was clearly negative, no threshold of response to mite injury was apparent.

Fruit yields of the trees were not related to CMD (Fig. 2B), thus no thresholds of yield response to ERM injury were apparent (regressions models tested all had $r^{2}$ values $<0.12$ ). The literature indicates variable effects of ERM on yield as reviewed earlier, but the variation in fruit numbers set earlier in the season controlled yield more than the variation in size due to mites. Fruit quality parameters of firmness, percent soluble solids, starch rating, and

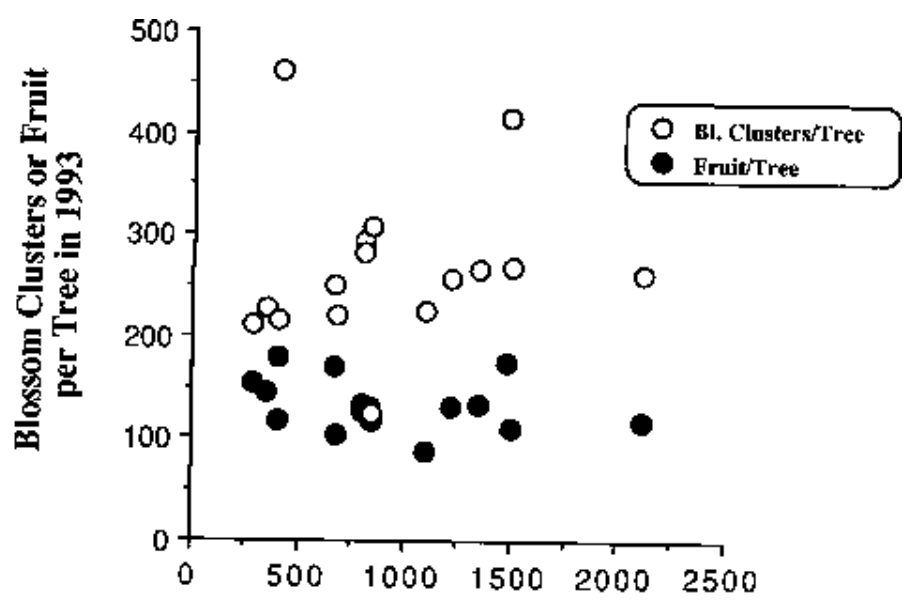

Final Cumulative Mite-Days in 1992

Fig. 3. Mean return bloom and final fruit numbers per tree of 'Starkrimson Delicious' apple trees in 1993 as related to cumulative mite-days of European red mites in 1992. 
visual color showed no clear responses to CMD levels with all regression $r^{2}$ values below 0.2 . Percent dry matter of the fruit declined 1.5 percentage points over the range of mite-days (percent dry matter $=12.1-0.0007 \mathrm{CMD}, r^{2}=0.48$ ).

Return bloom and final fruit numbers per tree in the following year, 1993, were not related to CMD in 1992 (Fig. 3). Return bloom and cropping were reduced by mite injury in some prior studies, but not in others (Beers and Hull, 1987, 1990; Beers et al., 1987; Hull and Beers, 1990; Lienk et al., 1956; Lienk and Minns, 1980). Since apple trees typically initiate and differentiate flower buds on spurs primarily in the first 6 to 8 weeks after bloom (Buban and Faust, 1982), late season foliar injury would not be expected to be the major factor affecting return flowering. However, late season stresses might limit flower bud development, thus potentially limiting final set in the following year. Clearly, results such as these cannot form the basis of sound pest management thresholds, even though the trees in this study were selected for good uniformity and were hand-thinned.

Physiological effects of mites. Post-injury leaf NCER of exposed leaves representative of the canopy and the mite injury declined with increasing CMD (Fig. 4A) as reported previously (Avery, 1963; Campbell et al., 1990; Ferree and Hall, 1980; Hall and Ferree, 1975; Mobley and Marini, 1990). Similarly, the mean midday whole-canopy NCER averaged over four post-injury dates in August and September declined with increasing CMD (Fig. 4B). The relative decline of NCER was similar in both cases, but $r^{2}$
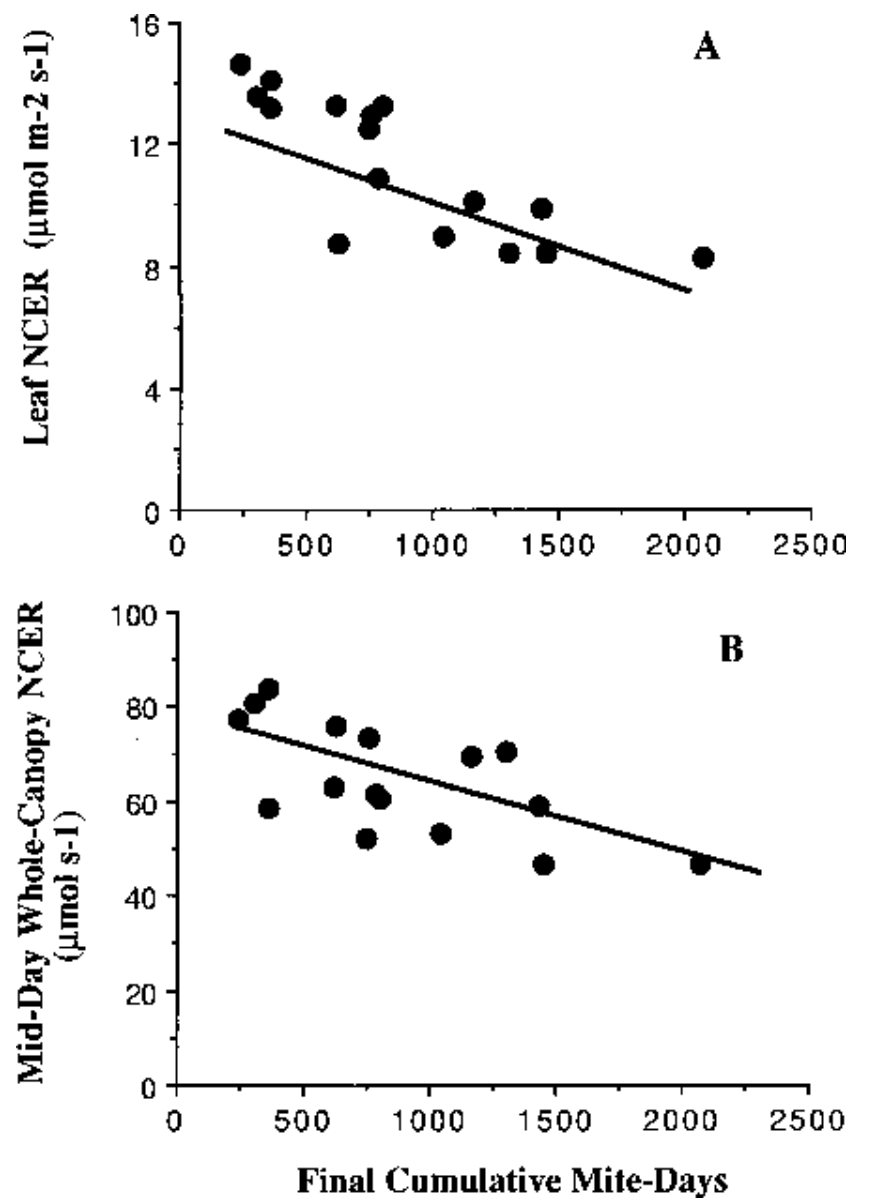

Fig. 4. Mean post-injury leaf net $\mathrm{CO}_{2}$ exchange rates (NCER) of exposed apple leaves (A) and of whole canopies of 'Starkrimson Delicious' apple trees (B) related to cumulative mite-days of European red mites. Regression equation for leaf NCER is y $=14.6-0.0037 \mathrm{CMD} r^{2}=0.66, P<0.001$; for whole-canopy NCER is $\mathrm{y}=77.9-0.015 \mathrm{CMD} r^{2}=0.43, P<0.006$. values of the whole-canopy NCER to CMD (0.43), was not as high as the $r^{2}$ of leaf NCER to CMD (0.66). This was expected since a greater number of factors affect whole-tree gas exchange (leaf areas, light interception, varying leaf exposures and ages, respiration of nonphotosynthetic organs) while the leaf NCER readings were restricted to leaves of similar age and exposure.

Although fruit growth and following year bloom or cropping were not highly correlated to CMD (Figs. 2A and 3), they were examined in relation to the mean whole-canopy NCER per fruit over four post-injury dates in August and September (a physiological expression of carbohydrate supply and demand). This expression should better integrate the natural variation in tree physiology, crop load, and environment known to affect apple cropping and fruit size. Final fruit weights were better correlated to wholecanopy NCER per fruit than to CMD (Figs. 5A vs. 2A). Also, the relationship of fruit weight to whole-canopy NCER per fruit appeared to have the asymptotic form that is expected with increasing carbohydrate supply for a given demand. Unfortunately, the natural and mite-induced variation in whole-canopy NCER per fruit was not sufficient to clearly define the full asymptotic curve expected due to the lack of lightly cropped, healthy trees in this study.
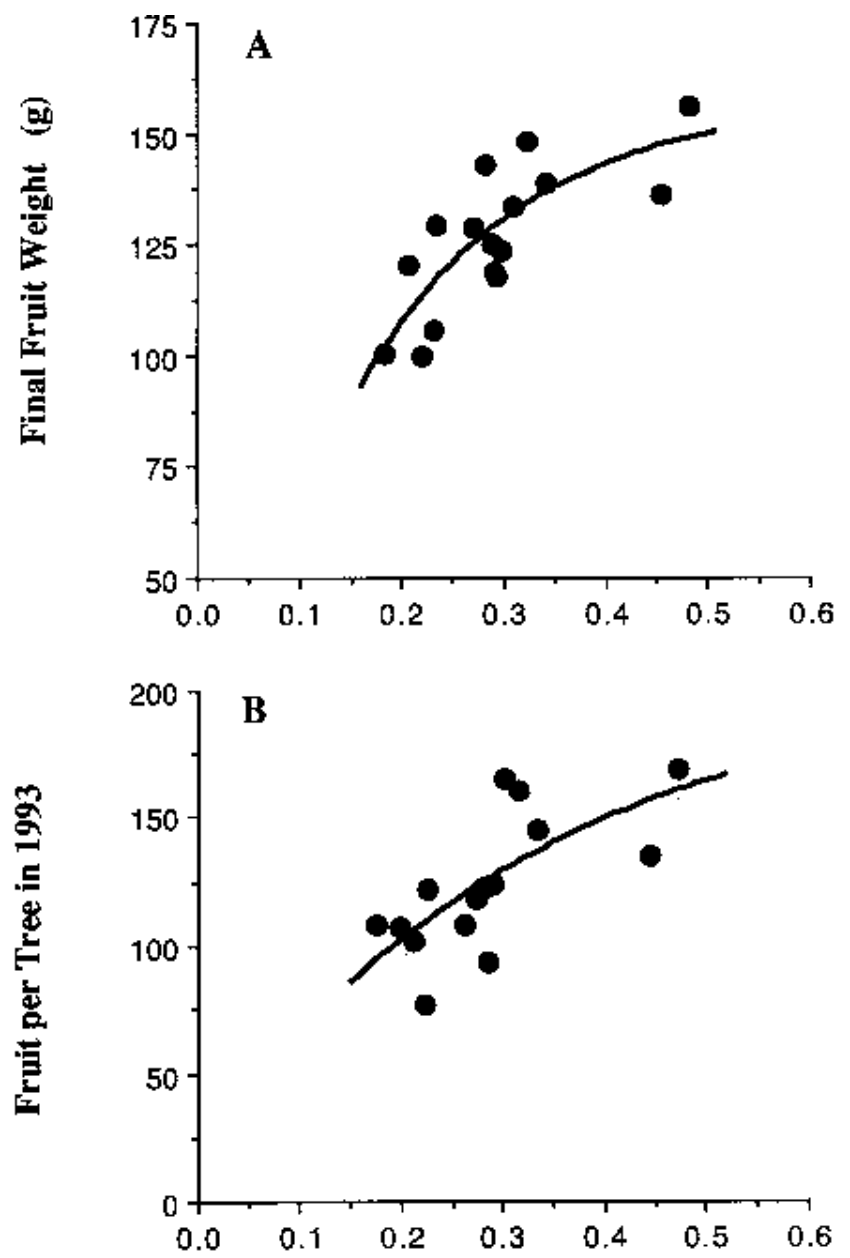

Canopy NCER ( $\mu$ mol s-1) per Fruit in 1992

Fig. 5. Mean final fruit weights in 1992 (A) and final fruit numbers in 1993 (B) of 'Starkrimson Delicious' apple trees related to whole-canopy net $\mathrm{CO}_{2}$ exchange rates (NCER) per fruit averaged four over post-mite-injury dates, an expression of carbohydrate supply/demand. Negative exponential regression equation for fruit weight is $\mathrm{y}=156-165 \times 0.0020^{\mathrm{NCER} / \text { fruit }} r^{2}=0.62, P<0.01$; for fruit per tree in 1993 is $\mathrm{y}=208-189.9 \times 0.053^{\text {NCER/fruit }} r^{2}=0.48, P<0.02$. 
Return bloom was not well correlated to post-injury canopy NCER per fruit, but the final fruit numbers per tree in the following year were clearly better correlated to canopy NCER per fruit after injury than to CMD alone (Figs. 5B and 3). Post-injury canopy NCER per fruit explained $48 \%$ of the variation in return cropping, suggesting that the ability of flowers to set fruit may be reduced by late season stresses the previous year. If this is confirmed, it indicates the need to maintain healthy foliage late in the season if annual heavy cropping is desired.

If carbohydrate supply/demand balance is the mechanism by which various foliar feeders affect apple tree productivity, there are several advantages: 1) carbohydrate physiology is one of the best understood and quantified aspect of plant physiology, 2) simulation modeling of carbohydrate physiology is quite advanced, and 3) it may provide a basis for developing multiple foliar pest thresholds. Although these results generally support the hypothesis and are promising, further research should extend the canopy NCER per fruit values with varying crop loads at differing mite levels to more fully define the interactions between crop load and ERM injury.

\section{Literature Cited}

Ames, G.K., D.T. Johnson, and R.C. Rom. 1984. The effect of European red mite feeding on the fruit quality of 'Miller Sturdeespur' apple. J. Amer. Soc. Hort. Sci. 109:834-837.

Avery, D.J. 1963. Carbon dioxide exchange by plum and apple leaves damaged by fruit tree red spider mite. Rpt. E. Malling Res. Sta. 1962:9497.

Beers, E.H., E.A. Elsner, S.R. Drake, and C.R. Rom. 1988. Effect of white apple leafhopper feeding injury on fruit size, fruit quality, and carbon dioxide uptake of apple. HortScience 23:746. (Abstr.)

Beers, E.H. and L.A. Hull. 1987. Effect of European red mite (Acari:Tetranychidae) injury on vegetative growth and flowering of four cultivars of apples. Environ. Entomol. 16:569-574.

Beers, E.H. and L.A. Hull. 1990. Timing of mite injury affects the bloom and fruit development of apple. J. Econ. Entomol. 83:547-551.

Beers, E.H., L.A. Hull, and G.M. Greene. 1990. Effect of a foliar urea application and mite injury on yield and fruit quality of apple. J. Econ. Entomol. 83:552-556.

Beers, E.H., L.A. Hull, and J.W. Grimm. 1987. Relationships between leaf:fruit ratio and varying levels of European red mite stress on fruit size and return bloom of apple. J. Amer. Soc. Hort. Sci. 112:608-612.

Buban, T. and M. Faust. 1982. Flower bud induction in apple trees: internal control and differentiation. Hort. Rev. 4:174-203.

Campbell, R.J., K.N. Mobley, and R.P. Marini. 1990. Growing conditions influence mite damage on apple and peach leaves. HortScience 25:445448.

Chapman, P.J., S.E. Lienk, and O.F. Curtis, Jr. 1952. Responses of apple trees to mite infestations: I. J. Econ. Entomol. 45:815-821.

Corelli Grappadelli, L. and E. Magnanini. 1993. A whole tree system for gas exchange studies. HortScience 28:41-45.

Ferree, D.C. and F.R. Hall. 1980. Effects of soil water stress and twospotted spider mites on net photosynthesis and transpiration of apple leaves. Photosynthesis Res. 1:189-197.

Flore, J.A. and A.N. Lakso. 1989. Environmental and physiological regulation of photosynthesis in fruit crops. Hort. Rev. 11:111-157.

Funderburk, J.E. 1993. Integrated pest management strategies for the future, p. 109-113. In: D.R. Buxton, R. Shibles, R.A. Forsberg, B.L. Blad, K.H. Asay, G.M. Paulsen, and R.F. Wilson (eds.). International crop science I. Crop Sci. Soc. Amer., Madison, Wis.

Hall, F.R. and D.C. Ferree. 1975. Influence of twospotted spider mite populations on photosynthesis of apple leaves. J. Econ. Entomol. 68:517520.

Haller, M.H. and J.R. Magness. 1933. Relation of leaf area and position to quality of fruit and to bud differentiation in apples. U.S. Dept. Agr.
Tech. Bul. 338 .

Hansen, P. 1977. Carbohydrate allocation, p. 247-258. In: J.J. Landsberg and C.V. Cutting (eds.). Environmental effects on crop physiology. Academic Press, London.

Hansen, P. and J.V. Christensen. 1974. Fruit thinning. III. Translocation of ${ }^{14} \mathrm{C}$ assimilates to fruit from near and distant leaves in the apple 'Golden Delicious'. Hort. Res. 14:41-45.

Higley, L.G., J.A. Browde, and P.M. Higley. 1993. Moving towards new understandings of biotic stress and stress interactions, p. 749-754. In: D.R. Buxton, R. Shibles, R.A. Forsberg, B.L. Blad, K.H. Asay, G.M. Paulsen, and R.F. Wilson (eds.). International crop science I. Crop Sci. Soc. Amer., Madison, Wis.

Hull, L.A. and E.H. Beers. 1990. Validation of injury thresholds for European red mite (Acari:Tetranychidae) on 'Yorking' and 'Delicious' apple. J. Econ. Entomol. 83:2026-2031.

Jackson, J.E. 1980. Light interception and utilization by orchard systems. Hort. Rev. 2:208-267.

Lakso, A.N. 1992. The simplified dry matter production model for apple: estimation of canopy photosynthesis in discontinuous canopies. Acta Hort. 313:45-51.

Lakso, A.N. 1994. Environmental physiology of the apple, p. 3-42. In: B. Schaffer and P.C. Andersen (eds.). Environmental physiology of fruit crops. CRC Press, Boca Raton, Fla.

Lakso, A.N. and L. Corelli Grappadelli. 1992. Implications of pruning and training practices to carbon partitioning and fruit development in apple. Acta Hort. 322:231-239.

Lakso, A.N. and R.S. Johnson. 1990. A simplified dry matter production model for apple using automatic programming simulation software. Acta Hort. 276:141-148.

Lakso, A.N., T.L. Robinson, and R.M. Pool. 1989. Canopy microclimate effects on patterns of fruiting and fruit development in apples and grapes, p. 263-274. In: C.J. Wright (ed.). Manipulation of fruiting. Butterworths, London.

Lienk, S.E., P. Chapman, and O.F. Curtis Jr. 1956. Responses of apple trees to mite infestations: II. J. Econ. Entomol. 49:350-353.

Lienk, S.E. and J.C. Minns. 1980. Effect of early mite feeding on apple. N.Y. State Hort. Soc. 125:93-96.

Marini, R.P., D.G. Pfeiffer, and D.S. Sowers. 1994. Influence of European red mite (Acari:Tetranychidae) and crop density on fruit size and quality and on crop value of 'Delicious' apples. J. Econ. Entomol. 87:13021311.

Mobley, K.N. and R.P. Marini. 1990. Gas exchange characteristics of apple and peach leaves infested by European red mite and twospotted spider mite. J. Amer. Soc. Hort. Sci. 115:757-761.

Oliveira, C.M. and C.A. Priestley. 1988. Carbohydrate reserves in deciduous fruit trees. Hort. Rev. 10:403-430.

Palmer, J.W., Y.-L. Cai, and Y. Edjamo. 1991. Effect of part-tree flower thinning on fruiting, vegetative growth and leaf photosynthesis in 'Cox's Orange Pippin' apple. J. Hort. Sci. 66:319-325.

Pedigo, L.P., S.H. Hutchins, and L.G. Higley. 1986. Economic injury levels in theory and practice. Annu. Rev. Entomol. 31:341-368.

Reissig, W.H., R.W. Weires, and C.G. Forshey. 1982. Effects of Gracillariid leafminers on apple tree growth and production. Environ. Entomol. 11:958-963.

Stern, V.M., R.F. Smith, R. van den Bosch, and K.S. Hagen. 1959. The integrated control concept. Hilgardia 29:81-101.

Welter, S.C. 1989. Arthropod impact on plant gas exchange, p. 135-150. In: E.A. Bernays (ed.). Insect-plant interactions. vol. 1. CRC Press, Boca Raton, Fla.

Welter, S.C. 1993. Responses of plants to insects: eco-physiological insights, p. 773-778. In: D.R. Buxton, R. Shibles, R.A. Forsberg, B.L. Blad, K. H. Asay, G.M. Paulsen, and R.F. Wilson (eds.). International crop science I. Crop Sci. Soc. Amer., Madison, Wis.

Williams, M.W. 1979. Chemical thinning of apples. Hort. Rev. 1:270300.

Zwick, R.W., G.J. Fields, and W.M. Mellenthin. 1976. Effects of mite population density on 'Newtown' and 'Golden Delicious' apple tree performance. J. Amer. Soc. Hort. Sci. 101:123-125. 